\title{
ЛЕКСИЧНІ ЗАСОБИ ВЕРБАЛІЗАЦІЇ КОНЦЕПТУ НАЦІОНАЛЬНА ІДЕНТИЧНІСТЬ У АНГЛОМОВНОМУ ДИСКУРСІ ПОЛІТИЧНИХ ПУБЛІЧНИХ ВИСТУПІВ
}

\begin{abstract}
Анотація. У статті висвітлюються проблеми особливостей вербалізації концепту НАЦІОНАЛЬНА ІДЕНТИЧНІСТЬ в англомовному політичному дискурсі на матеріалі політичних публічних виступів Б. Обами, Д. Трампа та Дж. Байдена (передвиборчі, президентські, інавгураційні промови, дипломатичні виступи в НАТО чи ООН). Підкреслено, що політична комунікащія реалізується через мовностилістичні особливості політичної риторики, а також через способи репрезентації ментального світу особистості в мові, особливості категоризації та концептуалізації дійсності, що фороме ідіостиль і когнітивний спосіб викладу політика. Виявлено специфіку структурних складників концепту «СВОЇ» і «ЧУЖІ», доведено, що для позначення американської нації (компонент концепту СВОї) президенти США у своїх промовах використовують нейтрально та позитивно забарвлені номінативні одиниці та дефінітивні лексеми. Проведено кількісний аналіз за ключовими словами концептосфери НАЦІОНАЛЬНА ІДЕНТИЧНІСТЬ, на основі аналізу етнонімів досліджено частоти їх вживання в протокольних промовах.
\end{abstract}

Ключові слова: національна ідентичність, концепт, вербалізація, політичні публічні виступи, оцінні номінації.

Fil Yaryna, Tsiokh Larysa Lviv Polytechnic National University

\section{LEXICAL MEANS OF THE CONCEPT NATIONAL IDENTITY VERBALIZATION IN THE ENGLISH LANGUAGE DISCOURSE OF POLITICAL PUBLIC SPEECHES}

Summary. The article highlights the problems of NATIONAL IDENTITY concept verbalization in English-language political discourse. The research is based on political public speeches by B. Obama, D. Trump and J. Biden (election, presidential, inaugural speeches, diplomatic speeches in NATO or the UN). The relevance of the study is determined by the importance of the phenomenon of national identity as a cultural constant of the United States as a unique state characterized by, on the one hand, multinationalism, and on the other - by the unity of the American people. It is emphasized that political communication is realized through the linguistic and stylistic features of political rhetoric, as well as through the ways of the mental personality world representation in language, and the features of categorization and conceptualization of reality. Moreover, political rhetoric outlines the idiostyle and the cognitive manner of politics presenting, and this question is of particular interest to linguists. It has been found that national identity, one of the key concepts of American culture, is determined by natural, historical, and cultural factors. The specifics of the NATIONAL IDENTITY concept structural components - "NATIVE" and "FOREIGN" are revealed. To denote the American nation (a component of the OWN concept), US presidents use neutrally and positively colored nominative units and definite tokens in their speeches. The reflection of national identity is also manifested in negatively valued tokens to denote foreigners. The subject of the NATIONAL IDENTITY concept is complete with lexical units that represent the government, individual representatives of the particular political sphere or the entire political system of America. A quantitative analysis of the conceptual sphere NATIONAL IDENTITY keywords was conducted, the most frequent (President - 39\%) and least frequent (Foreign Minister - less than 1\%) keywords in American political speeches were derived. Based on the analysis of ethnonyms, the frequencies of their use in protocol speeches were studied; it was found that the ethnonym American - the most widespread - completes $37 \%$ of the total number in American public speeches; least widespread - Palestine - less than 1\%.

Keywords: national identity, concept, verbalization, political public speeches, evaluation nominations.

$\Pi^{2}$ остановка проблеми. Дослідження різних аспектів політичної комунікації вже давно знаходяться в центрі уваги дослідників різних галузей, серед яких особливе місце займає політична лінгвістика. До актуальних проблем сучасної політичної лінгвістики належить вивчення політичної мови, зокрема, з'ясування особливостей фрункціонування лексичних і граматичних засобів у політичному дискурсі. Важливе завдання політичного дискурсу - впливати на індивідуальну і масову свідомість за допомогою різноманітних мовних засобів. Політична комунікація реалізуеться через мовностилістичні особливості політичної риторики, а також способи репрезентації ментального світу особистості в мові, особливості категоризації та концептуалізації дійсності. Більш того, політична риторика формує ідіостиль і когнітивний спосіб викладу політика, що викликає особливий інтерес лінгвістів.

Аналіз останніх досліджень і публікацій. Особливості політичного дискурсу та їі ступеня маніпулювання, розкриття механізмів політичної комунікащії $є$ важливим при визначенні характеристик мови як засобу впливу. Таким чином, здатність маніпулювати людською свідомістю через мову викликає особливий інтерес вчених. Класичними працями, які стосуються проблем політичного дискурсу, є праці Т. ван Дейка, Дж. Хабермаса, Е. Бенвеніста та М. Фуко. Деякі аспекти політичного дискурсу відображені також у працях вітчизняних та зарубіжних вчених, серед яких слід зазначити Ф. Бацевича, Н. Кондратенко, Н. Петлюченко, Л. Славову, О. Селіванову, Р. Помірко, А. Вежбицьку, К. Серажим, 
Дж. Мейер, Д. Таннен, Е. Лассан, Л. Синельникової, А. Чудінова, О. Шейгал та багатьох інших.

Тему національної ідентичності досліджував британський вчений Е. Сміт. Він у своїй пращі констатуе: «Сьогодні національна ідентичність становить головну форому колективної ідентифрікації» [3, с. 33]. Е. Сміт вважає, що компонентами національної ідентичності є: історична територія; спільні міфи та історична пам'ять; спільна масова громадська культура; єдині юридичні права та обов'язки всіх членів; спільна економіка 3 можливістю пересуватися в межах національної території [3, с. 24]. Е. Сміт надає значної уваги діалектиці колективної та індивідуальної в ідентичності, бо, «якщо ми хочемо зрозуміти поняття національної ідентичності, маємо зрівноважувати їх» [3, с. 24].

Виділення не вирішених раніше частин загальної проблеми. Однією 3 найактуальніших завдань, що стоять перед сучасними державами, є забезпечення національної єдності, формування загальнонаціональних соціальних та духовно-культурних засад суспільства. Найважливішу роль у цьому процесі грає національна ідентичність. Традиційно національна ідентичність виступала об'ектом вивчення сощіальних та політичних наук, оскільки вона $є$ результатом соціальних відносин. 3 точки зору ж нової наукової парадигми, яка розглядає мову у тісному взаємозв'язку з мисленням, практичною й духовною діяльністю людини, її особистістю та знаннями про світ, проблема національної ідентичності потребуе комплексного підходу, а тому має бути досліджена у взаємозв'язку з такими феноменами, як нація, етнос, культурна та громадянська цінність, культурна та громадянська ідентичність, негативна ідентичність, національна культура, національна ідея [5; 6] Саме цьому буде сприяти виявлення особливостей вербалізації національної ідентичності США в англомовному політичному дискурсі. Тому актуальність дослідження визначається важливістю феномена національної ідентичності як культурної константи Сполучених Штатів Америки, що є унікальною державою, для якої характерна, 3 одного боку, мультинаціональність, а 3 іншого - єдність американського народу.

Мета статті. Головною метою нашої статті є визначення лексичних засобів вербалізації концепту НАЦІОНАЛЬНА ІДЕНТИЧНІСТЬ у дискурсі політичних публічних виступів Б. Обами, Д. Трампа та Дж. Байдена. Матеріалом дослідження стали передвиборчі, президентські, інавгураційні промови, дипломатичні виступи в НАТО чи ООН (всього 91 текст).

Виклад основного матеріалу. Концепція національної ідентичності має не таку довгу власну історію - попри те, що вона викликає на сьогодні численні дискусії серед науковців і політиків, а також провокуе запеклі політичні баталії, які загострюються щоразу у передвиборчий період у демократичних країнах і спричиняють нерідко збройні зіткнення у країнах недемократичних [5, с. 140]. Хоча бої за національну незалежність і пов'язана з цим повсякденна робота щодо згуртовування нації тривають вже не перше століття, однак сам концепт «національна ідентичність» $є$ доволі недавнім. Тривалий час проблематика національної ідентичності визрівала в лоні дискусій щодо національного суверенітету і національної ідеї.

НАЦІОНАЛЬНА ІДЕНТИЧНІСТЬ - це один із ключових концептів американської культури. Це питання привертало увагу багатьох зарубіжних та вітчизняних дослідників, які надають різні визначення національної ідентичності, але думки багатьох вчених збігаються, що американська нащіональна ідентичність грунтуеться на засадах прав, свобод та рівності. Важливим аспектом вивчення американської національної ідентичності виступає мультикультуралізм нацї.

Слід зазначити, що в культурології та міжкультурній комунікації ідентичність (лат. identicus тотожний, той, що збігається) є основою національного та культурного ототожнення, індикатором СВОГО на противагу - ЧУЖОМУ. НАЦІОНАЛЬНА ІДЕНТИЧНІСТЬ визначається фракторами природної, історичної та культурної спільності. Відображення НАЦІОНАЛЬНОІ ІДЕНТИЧНОСТІ проявляеться й у використанні негативно оцінних лексем на позначення чужинщів.

Компоненти концепту СВОї в політичному дискурсі США представляють нейтрально та позитивно забарвлені лексеми: fellow-Americans, brothers and sisters, people of America, my dear good people, fellow delegates, ladies and gentlemen. Для позначення американської нації президенти США у своїх промовах використовують номінативні одинищі позитивно ощінної семантики: fine men, peace and friendship, the best of America.

Характеристика нащії відбувається за допомогою номінативної конструкщії, де зазначено, що всі ознаки - СВОЇХ, тобто американців, $є$ повністю відсутні в - ЧУЖИХ екстремістів / терористів: a nation that deadly longs for both. Варто підкреслити, що стосовно представників - CBОÏХ президенти використовують часто найвищий ступінь порівняння прикметника good - best.

МИ / СВОї ХОРОШІ - ВОНИ / ЧУЖІ ПОГАНІ представляються антонімічними групами: liberty and tyranny, justice and oppression, hope and despair тощо.

Досить часто можна зустріти у промовах метафроричні звернення для позначення представників чужих держав з допомогою зоонімних компонентів - coyotes (cayotes), jackals, drone тощо.

Суб'єкт концепту НАЦІОНАЛЬНА ІДЕНТИЧНІСТЬ заповнюеться лексичними одиницями, які позначають уряд, окремих представників політикуму або всю політичну систему Америки наприклад: Commander-in-Chief, White House та такими нейтральними лексемами як: authorities, leaders, politicians, government, Senate, Washington, Congress тощо.

Наведемо кілька прикладів використання лексичних одиниць на позначення СУБ'ЄКТУ концепту НАЦІОНАЛЬНА ІДЕНТИЧНІСТЬ:

(1) And even before I got to the U.S. Senate, when I was in the State Senate in Illinois, I passed legislation to try to reduce the incidents of racial profiling by collecting data. And that was prompted by evidence that it was taking place in certain parts of the state (Б. Обама, Press Conference Following NATO Summit);

(2) Now, the first time I addressed this convention in 2004, I was a younger man, a Senate 
candidate from Illinois, who spoke about hope - not blind optimism, not wishful thinking, but hope in the face of difficulty; hope in the face of uncertainty; that dogged faith in the future which has pushed this nation forward, even when the odds are great, even when the road is long (Б. Обама, Nominee Acceptance Speech at 2012 Democratic National Convention);

(3) And, by the way, those of us who carry on his party's legacy should remember that not every problem can be remedied with another government program or dictate from Washington (Б. Обама, Nominee Acceptance Speech at 2012 Democratic National Convention);

(4) As President of our country and Commanderin-Chief of our military, I accept that people are going to call me awful things every day - and I will always defend their right to do so (Б. Обама, 67 th Session of the United Nations General Assembly Address);

(5) As Commander-in-Chief, I will never hesitate to defend this nation, but I will only send our troops into harm's way with a clear mission and a sacred commitment to give them the equipment they need in battle and the care and benefits they deserve when they come home (Б. Обама, Acceptance Speech at the Democratic National Convention);

(6) As just one example, I recently met the CEO of a terrific American company, Micron Technology, at the White House (Д. Трамп, 74th Session of the United Nations General Assembly).

Проведемо кількісний аналіз за ключовими словами концептосфери НАЦІОНАЛЬНА ІДЕНТИЧНІСТЬ, які переважають у всіх промовах президентів США (табл. 1).

Серед ключових слів в американських промовах переважає слово President - 787 разів (39\%), а найменш вживаним виявилось ключове слово Foreign Minister - 1 раз (менше 1\%).

Таблиця 1

Кількісний аналіз лексем, які позначають уряд, представників уряду США

\begin{tabular}{|c|c|}
\hline $\begin{array}{c}\text { Лексеми, } \\
\text { які позначають уряд, } \\
\text { представників уряду }\end{array}$ & $\begin{array}{c}\text { Кількість вживань } \\
\text { публічих виступах }\end{array}$ \\
\hline Commander-in-Chief & 19 \\
\hline White House & 90 \\
\hline Congress & 200 \\
\hline Authorities & 10 \\
\hline Leaders & 160 \\
\hline Politician & 12 \\
\hline Government & 321 \\
\hline Senate & 105 \\
\hline Delegate & 3 \\
\hline Washington & 130 \\
\hline President & 787 \\
\hline Prime Minister & 23 \\
\hline Foreign Minister & 1 \\
\hline Secretary & 151 \\
\hline Ladies and gentlemen & 7 \\
\hline Senator & 6 \\
\hline
\end{tabular}

Джерело: розроблено авторами
Часово-просторові рамки виступають фоном, на тлі якого фороруеться та фоункціонуе НАЦІОНАЛЬНА ІДЕНТИЧНІСТЬ. Актуалізуеться час як компонент моделі концепту НАЦІОНАЛЬНА ІДЕНТИЧНІСТЬ, в якому можна виокремити позначення важких періодів для держави (терористичні акти, війни або катастрофи), так і святкові дати. Цей слот заповнюеться такими лексичними одиницями як 9/11, age of terror / terrorism, tough times, globalization, time of joy and prosperity, it's the time of us, it's our time, war, війна, окупаиія, анексія, тероризл тощо.

(1) Next year, an international coalition will end its war in Afghanistan, having achieved its mission of dismantling the core of al Qaeda that attacked us on 9/11 (Б. Обама, 68th Session of the United Nations General Assembly Address);

(2) For while Senator McCain was turning his sights to Iraq just days after 9/11, I stood up and opposed this war, knowing that it would distract us from the real threats we face. When John McCain said we could just "muddle through" in Afghanistan, I argued for more resources and more troops to finish the fight against the terrorists who actually attacked us on 9/11, and made clear that we must take out Osama bin Laden and his lieutenants if we have them in our sights (Б. Обама, Acceptance Speech at the Democratic National Convention);

(3) I have the list of exactly how many have died: 547,296 Americans dead from the virus - more than all the people killed in World War One, World War Two, the Vietnam War, 9/11. 547,296 Americans (Джо Байден, Announcing the American Jobs Plan);

(4) According to data provided by the Department of Justice, the vast majority of individuals convicted for terrorism-related offenses since $\mathbf{9 / 1 1}$ came here from outside of our country (Д. Трамп, Address to Joint Session of Congress).

Мовні одинищі, що наповнюють модель концепту НАЦІОНАЛЬНА ІДЕНТИЧНІСТЬ, поділено на топоніми, виражені прямою і вторинною номінаціями. До першої групи належать офріційні назви країни та їі регіонів, наприклад America, the USA, the US, Cansas City, Ukraine, Russia тощо.

У своїх промовах американські політики надають також і оцінку (зазвичай позитивну) мешканцям Америки, протиставляючи їх зовнішнім ворогам. У цьому випадку простежується актуалізація опозищї СВОЇ/ЧУЖІ. Наприклад: is a cool man, a burning element, enemy, void, у таких прикладах:

(1) After all, you don't call Russia our numberone enemy - not al Qaeda - Russia - unless you're still stuck in a Cold War mind warp (Б. Обама, Final Address to the United Nations General Assembly);

(2) But when there's a vacuum in our democracy, when we don't vote, when we take our basic rights and freedoms for granted, when we turn away and stop paying attention and stop engaging and stop believing and look for the newest diversion, the electronic versions of bread and circuses, then other voices fill the void (Б. Обама, Address to the United Nations General Assembly).

На кожному мовному рівні існують певні засоби, використання яких в американському по- 
літичному дискурсі зумовлене оцінною моделЛю - СВОЄ - ДОБРЕ, ЧУЖЕ - ПОГАНЕ. Специфріка використання цих мовних засобів виключає їхню участь у створенні зворотної оцінки - СВОЕ - ППОГАНЕ, ЧУЖЕ - ДОБРЕ Категорія - СВІЙ - ЧУЖИЙ антропоцентрична, тому при активізації одного 3 концептів завжди відбувається його зіставлення із суб'єктом [6, с. 6].

Актуалізація ЧУЖИЙ відбувається через пряме називання ворогів американської нації:

(1) In Kenya, we've seen terrorists target innocent civilians in a crowded shopping mall, and our hearts go out to the families of those who have been affected (Б. Обама, 68th Session of the United Nations General Assembly Address);

(2) And to do that, we must confront the common enemies of humanity: nuclear weapons and poverty, ignorance and disease. These forces corrode the possibility of lasting peace and together we're called upon to confront them (Б. Обама, 66th Session of the United Nations General Assembly Address);

(3) They knew they were part of something larger - a nation that triumphed over fascism and depression; a nation where the most innovative businesses turned out the world's best products. And everyone shared in that pride and success, from the corner office to the factory floor (Б. Обама, Nominee Acceptance Speech at 2012 Democratic National Convention).

Розглянемо також специфріку актуалізації поняття $C В I И ̆$ у політичному дискурсі США через засоби вербалізащії цього поняття щодо самих американщів, які і є носіями національної ідентичності. Безумовно, найуживанішою лексичною одиницею для позначення мешканців США $є$ нейтральний етнонім American.

У промовах Б. Обами, Д. Трампа та Дж. Байдена цей етнонім ілюструють такі приклади:

(1) I took office at a time when many around the world had come to view America with skepticism and distrust. Part of this was due to misperceptions and misinformation about my country. Part of this was due to opposition to specific policies, and a belief that on certain critical issues, America has acted unilaterally, without regard for the interests of others. And this has fed an almost reflexive anti-Americanism, which too often has served as an excuse for collective inaction ((Б.Обама, First Speech Before the United Nations General Assembly (64th Session));

(2) So, folks, there's no reason why AmericanAmerican workers can't lead the world in the production of electric vehicles and batteries (Дж. Байден, Address to Joint Session of Congress);

(3) The American people are strong and resilient, and they will emerge from these hardships more determined than ever before (Д. Трамп, Trump's 2017 U.N. speech transcript).

На основі аналізу етнонімів прослідковуеться частота їх вживання в промовах (рис. 1).

Результатом частотного аналізу етнонімів у складі промов США, було виявлено, що етнонім American - найбільш вживаний - 37\% в американських публічних виступах. Найменш вживаним є Palestine - менше $1 \%$.

Висновки i пропозиції. Отже, НАЦІОНАЛЬНУ ІДЕНТИЧНІСТЬ можна представити як символічний простір, що глибоко вкоренився, завдяки аналізу психологічного, культурологічного, історичного, територіального та політичного вимірів національної ідентичності. У џьому просторі спільність людей перетворюеться на спільність національну, здатну відрізняти себе від «чужих» та створити власну культуру, систему моральних та суспільних цінностей, культурних норм та ідеалів. НАЦІОНАЛЬНА ІДЕНТИЧНІСТЬ асоціюеться 3 понятТями самобутності, наступності, стійкості, ототожнення та усвідомлення своєї етнічної та національної належності та характеризуеться якісною визначеністю. Це прослідковуеться на рівні когнітивних ознак концепту, зумовлюе їх частотність та специфіку слів-вербалізаторів.

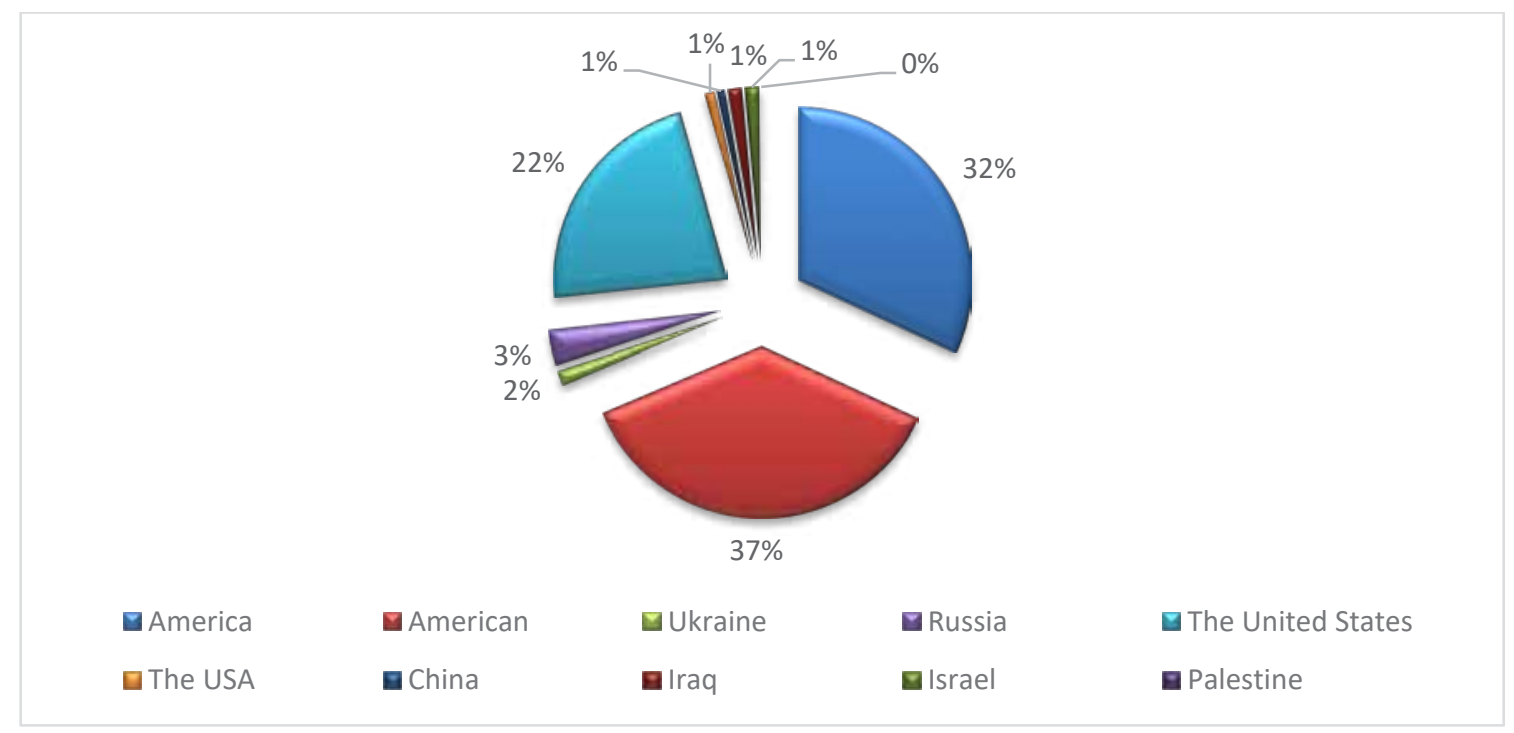

Рис. 1. Частота вживання етнонімів в промовах американських президентів 


\section{Список літератури:}

1. Бутова I. С. Політичний дискурс: полеміка навколо. Міжнародний бізнес та менеджмент: проблеми та перспективи в умовах глобалізації : матеріали міжнар. наук.-практ. конф. (Тернопіль, 22-24 жовтня 2008 р.). Тернопіль, 2008. С. 488-490.

2. Кущ Е. О. Метонімічні номінації як засоби вираження етнічних упереджень у дискурсі американських політиків. Нова фбілологія. Запоріжжя, 2013. № 53. С. 62-65.

3. Сміт Ентоні. Національна ідентичність. Київ, 1994. 224 с.

4. Чернишенко I. А. Ціннісні концепти в американській мовній картині світу. Мовні і концептуальні картини світу. Київ, 2006. Вип. 20. С. 126-131.

5. Четвертак Є. О. Стратегія позитивної самопрезентації американської нації у політичному дискурсі США. Нова фбілологія. Запоріжжя, 2014. № 67. С. 139-143.

6. Четвертак Є. О. Стратегія репрезентації американської національної ідентичності в політичному дискурсі США. Актуальні проблели фбілологї̈ та перекладознавства. Хмельницький, 2016. Вип. 10. Т. 3. С. $213-219$.

7. Barack Obama. URL: https://americanrhetoric.com/barackobamaspeeches.htm (дата звернення: 10.11.2021).

8. Donald Trump. URL: https://millercenter.org/the-presidency/presidential-speeches?field_president_target_id [8396]=8396 (дата звернення: 10.11.2021).

9. Joe Biden. URL: https://millercenter.org/the-presidency/presidential-speeches?field_president_target_id[8396]= 8396 (дата звернення: 10.11.2021).

\section{References:}

1. Butova I. S. (2008) Politychnyy dyskurs: polemika navkolo [Political discourse: controversy around]. Proceedings of the Mizhnarodnyy biznes ta menedzhment: problemy ta perspektyvy $v$ umovakh hlobalizatsiyi (Ternopil, October 22-24, 2008). Ternopil, pp. 488-490. (in Ukrainian)

2. Kushch E. O. (2013) Metonimichni nominatsii yak zasoby vyrazhennia etnichnykh uperedzhen u dyskursi amerykanskykh politykiv [Metonymic nominations as a means of expressing ethnic prejudices in the discourse of American politicians]. New philology, no. 53, pp. 62-65. (in Ukrainian)

3. Smit Entoni (1994) Natsionalna identychnist [National Identity]. Kyiv: Osnovy.

4. Chernyshenko I. A. (2006) Tsinnisni kontsepty v amerykanskiy movniy kartyni svitu [Value concepts in the American language picture of the world]. Linguistic and conceptual pictures of the world, vol. 20, pp. $126-131$. (in Ukrainian)

5. Chetvertak Ye. O. (2014) Stratehiya pozytyvnoyi samoprezentatsiyi amerykanskoyi natsiyi u politychnomu dyskursi SShA [The strategy of positive self-presentation of the American nation in US political discourse]. New philology, no. 67, pp. 139-143. (in Ukrainian)

6. Chetvertak Ye. O. (2016) Stratehiia reprezentatsii amerykanskoi natsionalnoi identychnosti v politychnomu dyskursi SshA [Strategy of the American National Identity Representation in US Political Discourse]. Current issues of philology and translation studies, vol. 10, no. 3, pp. 213-219. (in Ukrainian)

7. Barack Obama. Available at: https://americanrhetoric.com/barackobamaspeeches.htm (accessed 10 November 2021).

8. Donald Trump. Available at: https://millercenter.org/the-presidency/presidential-speeches?field_president_ target_id[8396]=8396 (accessed 10 November 2021).

9. Joe Biden. Available at: https://millercenter.org/the-presidency/presidential-speeches?field_president_target_ id[8396]=8396 (accessed 10 November 2021). 